Jurnal Konstruksi Hukum | ISSN: XXXX | E-ISSN: XXXX Vol. 1, No. 1, September 2020 Hal. 120-124| Available online at https://www.ejournal.warmadewa.ac.id/index.php/jukonhum

DOI: https://doi.org/10.22225/jkh.1.1.2143.120-124

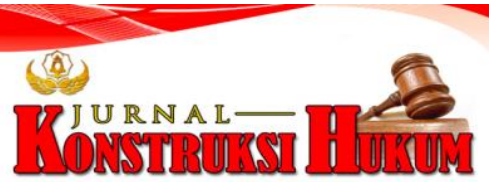

\title{
SANKSI PIDANA TERHADAP PENGASUH TEMPAT PENITIPAN ANAK TERHADAP KEMATIAN ANAK YANG DIASUH
}

\author{
Gede Made Agus Paramartha, I Ketut Sukadana, I Made Minggu Widyantara \\ Fakultas Hukum Universitas Warmadewa, Denpasar - Bali, Indonesia
}

\begin{abstract}
Abstrak
Anak merupakan salah satu karunia atau titipan yang diberikan oleh Tuhan Yang Maha Esa kepada setiap orang tua. Mereka mendapatkan kewajiban untuk mengawasi dan menjaga perkembangan setiap anak. Anak juga sudah semestinya dipelihara dengan baik oleh orang tuanya, tetapi tidak jarang anak dipelihara oleh orang lain melalui jasa penitipan anak. Pada saat anak dalam pengawasan di jasa penitipan anak, terjadi suatu kelalaian yang dilakukan oleh si pengasuh, sehingga menyebabkan kematian pada si anak tersebut. Berdasarkan latar belakang tersebut penelitian ini bertujuan untuk mendeskripsikan bagaimana perlindungan hukum terhadap anak yang dititipkan di tempat penitipan anak dan apa sanksi pidana bagi pengasuh tempat penitipan anak terhadap kematian anak. Penelitian ini dilakukan dengan menggunakan metode hukum normatif. Hasil penelitian ini menunjukkan bahwa Anak yang dititipkan ditempat penitipan anak mendapatkan perlindungan hukum untuk menghindari anak mendapatkan perbuatan yang mengancam kejiwaan anak tersebut. Perlindungan hukum itu secara khusus diatur dalam Undang-Undang Nomor 35 Tahun 2014 mengenai perlindungan anak. Selain itu, sanksi pidana bagi pengasuh tempat penitipan anak terhadap kematian anak merujuk pada pada pasal 359 KUHP dengan risiko hukuman 5 tahun penjara.
\end{abstract}

Kata Kunci: Kematian anak; Sanksi pidana; Tempat penitipan anak

\begin{abstract}
Children are one of the gifts entrusted by God Almighty to every parent. They have the obligation to supervise and maintain the development of each child. Children should also be cared for properly by their parents, but it is not uncommon for children to be cared for by others through child care services. When a child is under supervision at a child care service, there is negligence by the caregiver which causes the death of the child. Based on this background, this study aimed to describe how the legal protection for children who are left in a child care center and what are the criminal sanctions for the caregivers of child care center toward child deaths. This research was conducted using the normative legal method. The results of this study showed that children who are left in a child care center get legal protection to prevent children from getting acts that threaten the child's psyche. Legal protection is specifically regulated in Law Number 35 of 2014 concerning child protection. In addition, the criminal sanction for caregivers of child care toward the death of a child refers to article 359 of the Criminal Code with the risk of a sentence of 5 years in prison.
\end{abstract}

Keywords: Child mortality; Criminal sanction; Child care enter

\section{PENDAHULUAN}

Peran anak yaitu meneruskan cita-cita bangsa. Anak memiliki hak dan kewajiban di mana telah tercantum dalam Undang-Undang Nomor 35 Tahun 2014 mengenai perlindungan anak. Peran orang tua juga sangat menentukan bagaimana nantinya anak tersebut tumbuh menjadi seorang anak yang tidak hanya berguna untuk hidupnya sendiri tetapi berguna bagi bangsa dan Negara. Sebagai bagian dari penerus bangsa anak yang ada di Indonesia memiliki hak seperti yang sudah tertuang dan dinyatakan dalam konstitusi. Hak anak yang dimaksud adalah suatu keinginan yang sudah dilengkapi dengan kekuatan (macht) yang sudah dimiliki oleh anak dan yang diberikan oleh sistem hukum atau tertib hukum kepada anak yang bersangkutan (Lestari, 2017; Wijaya, 2015).

Jika kita melihat dari peran orang tua dalam mengawasi anak, tentunya banyak sekali pertimbangan yang harus dilewati seperti bagaimana perilaku orang tua serta masyarakat karena anak tanpa sengaja mencontoh perilaku orang dewasa di sekitarnya tanpa mengenal itu salah atau betul (Waluyo, 2000). 
Tanpa disadari sekarang ini banyak sekali tindakan yang tidak semestinya didapat anak. hal tersebut lantaran karena banyaknya persoalan hukum yang menyangkut pribadi anak. Keikutsertaan anak dalam persoalan hukum dan kepekaan masyarakat menjadi sangat kurang mengenai keseimbangan dan menyampingkan peran anak sebagai pelanjut cita-cita bangsa. Kondisi seperti itu sudah seharusnya menjadikan pemeliharaan yang khusus bagi orang tua dalam mengontrol kebiasaan anak. Anak adalah seseorang yang belum terlalu mengenal hal yang salah dan benar.

Orang tua mempunyai kewajiban penuh untuk merawat anaknya. Namun karena orang tua sangat sibuk bekerja dan kurang ada waktu untuk anak, anak akhirnya dipelihara oleh orang lain atau dititipkan di lembaga tempat penitipan anak (Candra, 2018; Puspita, 2019). Jika anak sudah dititipkan di lembaga tempat penitipan anak, maka tanggung jawab penuh untuk memelihara anak berada di bawah lembaga tempat penitipan anak tersebut (Purnamasari, 2018). Tetapi karena suatu kelalaian yang di lakukan oleh seorang pengasuh di tempat penitipan tersebut, salah satu anak di tempat penitipan anak meninggal dunia.

Berdasarkan latar belakang yang diuraikan di atas, penelitian ini dilakukan dengan tujuan mendeskripsikan bagaimana perlindungan hukum terhadap anak yang dititipkan di tempat penitipan anak dan apa sanksi pidana bagi pengasuh tempat penitipan anak terhadap kematian anak.

\section{METODE PENELITIAN}

Penelitian ini didesain dengan menggunakan metode penelitian hukum normatif karena pengkajiannya dilakukan dengan studi kepustakaan seperti perundang- undangan, teori hukum, dan dapat berupa pendapat para ahli hukum. Berdasarkan metode penelitian yang digunakan, penelitian ini menggunakan pendekatan perundang-undang dan pendekatan konseptual.

Adapun sumber bahan hukum yang digunakan yakni bersumber dari penelitian kepustakaan yaitu berupa bahan hukum primer, yaitu bahan-bahan hukum yang mengikat berupa Undang-Undang Dasar Negara Republik Indonesia Tahun 1945 (Undang-Undang Republik Indonesia 1945), Kitab Undang-Undang Hukum Pidana (KUHP), Undang-Undang Republik Indonesia Nomor 4 Tahun 1979 tentang Kesejahteraan Anak, Undang-Undang Nomor 11 Tahun 2012 mengenai Sistem Peradilan Pidana Anak, dan Undang-Undang Nomor 35 tahun 2014 mengenai Perlindungan Anak. Bahan hukum sekunder yaitu bahan-bahan hukum yang diperoleh dari pengkajian kepustakaan (Library Research) yaitu dengan membaca buku hukum jurnal-jurnal hukum surat kabar dan internet yang berkaitan dengan sanksi pidana terhadap pengasuh tempat penitipan anak terhadap kematian anak yang diasuh sebagai permasalahan yang dibahas.

Untuk memperoleh bahan-bahan hukum primer dan sekunder, teknik catat digunakan dengan membaca buku-buku peraturan perundang-undangan serta literatur lainnya yang berkaitan dengan permasalahan yang penulis bahas. Data-data yang sudah terkumpul selanjutnya disusun dan dianalisis secara sistematis dengan menggunakan argumentasi hukum berdasarkan logika hukum deduktif, dan hasilnya disajikan secara deskriptif analisis.

\section{HASIL DAN PEMBAHASAN}

\section{Perlindungan Hukum terhadap Anak yang Dititipkan di Tempat Penitipan Anak}

Perlindungan hukum hak asasi manusia diberikan kepada orang yang merasa dibebani oleh orang lain. Perlindungan hukum tersebut diperuntukkan untuk masyarakat agar merasakan hak yang diterima oleh hukum sebagai pokok hukum manusia mendapatkan hak dan kewajiban untuk melakukan suatu perbuatan hukum (Kansil, 1980).

Anak merupakan bagian dari cita-cita bangsa dan Negara. Untuk mewujudkan keinginan tersebut, perlu ada perlindungan hukum terhadap anak agar terhindar dari kekerasan. Untuk itu perlindungan yang paling utama kepada anak sudah seharusnya didapatkan dari orang paling terdekat yaitu orang tua.

Tempat penitipan anak merupakan bagian dari salah satu jasa yang menyelenggarakan program pendidikan non formal. Hal ini seharusnya memudahkan para orang tua yang bekerja dengan menitipkan anaknya karena pada dasarnya tempat penitipan anak memberikan layanan yang terkait dengan hak yang diperoleh seorang anak serta mendapatkan kasih sayang selain yang didapatkan dari orang tua.

Anak yang dititipkan di tempat penitipan anak mendapatkan perlindungan hukum untuk menghindari anak mendapatkan perbuatan yang mengancam kejiwaan anak tersebut. Perlindungan 
hukum itu secara khusus diatur dalam Undang-Undang Nomor 35 Tahun 2014 mengenai perlindungan anak.

Dengan ada pengaturan perlindungan hukum terhadap anak yang berada ditempat penitipan anak pada dasarnya untuk mengetahui bahwa terdapatnya pengaturan tersebut agar anak yang dititipkan mendapatkan hak serta memperoleh rasa aman baik terhadap anak itu sendiri maupun orang tua yang menggunakan jasa penitipan anak tersebut. Perlindungan hukum diberikan agar hak manusia sebagai pokok hukum dapat dilindungi serta mewujudkan disiplin kepada masyarakat dan dengan begitu maka pergaulan atau kebiasaan di masyarakat dapat terjaga dan teratur secara sistematis sesuai dengan Undang-Undang yang mengaturnya (Hadjon, 1987).

Untuk dapat membentuk kehidupan yang baik kepada anak, harus ada kerja sama dari pihak orang tua keluarga dan pemerintah. Anak memperoleh perlindungan khusus dalam situasi darurat. Terciptanya perlindungan hukum untuk anak sudah sepatutnya dilaksanakan sedini mungkin mengingat anak sebagai penerus cita-cita bangsa dan negara.

Kualitas perlindungan hukum untuk anak harus memiliki tingkatan dan derajat yang sama dengan orang dewasa dikarenakan anak sangat rentan terhadap kekerasan yang dilakukan oleh orang sangat rentan terhadap kekerasan yang dilakukan oleh orang dewasa dan dampak dari tidak ada pelindungan anak bisa terpengaruh terhadap mental dan kehidupan pribadinya dimasa yang akan datang.

Jika dilihat dari aspek hukum pidana merujuk pada Undang-Undang Nomor 35 Tahun 2014 mengenai perlindungan anak sudah ditegaskan bahwa anak mendapatkan perlindungan yang sebagaimana mestinya menurut peraturan yang sudah diatur. Dan untuk itu perlu ada kepedulian dari berbagai pihak tidak hanya keluarga terdekat saja melainkan dari berbagai aspek untuk mewujudkan keselamatan dan kedamaian kepada anak.

\section{Sanksi Pidana bagi Pengasuh Tempat Penitipan Anak terhadap Kematian Anak}

Pengasuh dinyatakan sebagai orang yang semestinya bertanggung jawab atas pertumbuhan seorang anak serta berperan memberikan kasih sayang dalam menjaga anak yang sudah dalam pengawasannya dan peran pengasuh membangun watak jiwa dan personalitas anak. Untuk itu dalam hal ini pengasuh diberikan amanat dalam melaksanakan kewajibannya sebagai pengasuh. Selain itu, anak yang berada didalam tempat penitipan anak seharusnya mendapatkan pengawasan yang ketat dan dijaga sesuai dengan etika dan disesuaikan dengan tanggung jawab profesi para pengasuh.

Sanksi pidana yaitu suatu kaidah dari risiko yang dimana risiko tersebut berupa hukuman orang yang menerima sanksi baik masuk penjara maupun terkena risiko lain dari pihak berwajib. Pidana itu sendiri berupa beban atau derita yang sengaja dipikul oleh orang yang menerima perbuatan yang memenuhi persyaratan dan ketentuan dan serta mempertegas sanksi belaka sebagai ancaman pidana sehingga hukum pidana adalah hukum sanksi belaka (Marlina, 2011).

Adanya kematian anak di dalam Tempat Penitipan Anak dapat dikatakan sebagai suatu wanprestasi (kealpaan) karena dilandasi atas suatu persetujuan antara para pihak di mana pihak Tempat Penitipan Anak menjaga anak selama berada di bawah penjagaannya. Tempat Penitipan Anak yang melakukan tindakan hukum yang tidak sesuai dengan peraturan dapat dijatuhi hukuman yaitu menggantikan dana dan kerugian karena Tempat Penitipan Anak tidak melakukan apa yang disanggupi akan dilakukannya salah satunya menjaga anak yang dititipkan di bawah pengawasannya. Ganti biaya dan kerugian tersebut diatur dalam Pasal 1239 KUH Perdata.

Namun jika merujuk pada Undang-Undang tersebut dikatakan belum dapat terlaksana kewajiban Indonesia mengenai pengasuh dan perlindungan anak. Oleh sebab itu, perencanaan Undang-Undang mengenai pengasuh anak dikatakan mampu menyediakan berbagai peristiwa pengasuhan anak. Di sini peran dan kewajiban pemerintah serta kepedulian masyarakat lebih ditegakkan untuk mencegah ada tindak pidana yang mengakibatkan anak menjadi korbannya.

Jika dilihat seacara umum pengasuh adalah orang dewasa yang ikut dalam bertanggungjawab demi pendidikan anak dan keberlangsungan hidup yang terdapat dalam penjelasan tersebut ialah ayah ibu nenek dan kakek (An-Nahlawi, 1995). Lalu pengasuhan yang sudah dilakukan oleh orang tua benar-benar sangat penting dalam tumbuh dan kembang anak.

Pengasuhan yaitu suatu cara terbaik yang dapat ditempuh orang tua dalam mengajar anakanaknya sebagai pelaksanaan dari rasa tanggung jawab kepada anak-anaknya sehingga sikap orang tua terhadap anaknya dalam memberikan andil yang sangat baik dalam metode pendirian karakter 
anak. Keluarga merupakan masyarakat pendidikan pertama kali bagi anak. Setiap orang tua mengharapkan anak-anaknya menjadi anak yang berkepribadian yang baik oleh karena itu dalam membentuk karakter anak harus diberikan pengasuhan yang baik sejak dini. Hal ini dikarenakan pendidikan pertama yang diterima oleh anak adalah pendidikan dari orang tua.

Dengan posisi yang sibuk dalam pekerjaannya orang tua tentunya akan mengurangi waktu kebersamaan bersama anaknya. Pada demikian keeratan orangtua dengan sang anak pun menjadi sangat kurang. Suatu akibat yang masuk akal dari ibu rumah tangga yang pada umumnya membimbing anak kini mulai berganti peranannya oleh asisten rumah tangga yang terkadang mempunyai banyak kesulitan baik dari segi biaya maupun pengetahuan yang sangat rendah tentang membimbing anak.

Karena setiap orang tua ingin memberikan pembimbingan yang terbaik untuk anaknya, agar dimasa yang akan datang menjadikan anak tersebut berguna tidak hanya untuk keluarga terdekat tetapi juga untuk bangsa dan Negara, sebagai penerus cita-cita bangsa. Dan sebagai orang tua bertanggung jawab atas beberapa bentuk pengawasan terhadap anak, yang dimana anak sering menjadi korban dalam suatu tindak pidana yang mengakibatkan jiwa dan kepribadian anak tersebut kurang baik dan tidak efektif.

Sanksi pidana yang dapat diberikan untuk Pengasuh Penitipan Anak merujuk dalam Undangundang Nomor 1 Tahun 1946 mengenai Kitab Undang- undang Hukum Pidana yaitu pada Bab VIII pasal 76B Jo., Pasal 77B Undang- Undang Nomor 35 tahun 2014 mengenai Perlindungan Anak, dan atau Pasal 359 KUHP. Sanksi pidana untuk Pengasuh Penitipan Anak merujuk pada pasal 359 KUHP dengan risiko hukuman 5 tahun penjara.

\section{SIMPULAN DAN SARAN}

\section{Simpulan}

Berdasarkan hasil dan pembahasan yang telah diuraikan di atas, ada beberapa simpulan yang dapat dibuat, yaitu: pertama, anak yang dititipkan ditempat penitipan anak mendapatkan perlindungan hukum untuk menghindari anak mendapatkan perbuatan yang mengancam kejiwaan anak tersebut. Perlindungan hukum itu secara khusus diatur dalam Undang-Undang Nomor 35 Tahun 2014 mengenai perlindungan anak. Kedua, sanksi pidana bagi pengasuh tempat penitipan anak terhadap kematian anak merujuk pada pada pasal 359 KUHP dengan risiko hukuman 5 tahun penjara.

\section{Saran}

Berdasarkan hasil penelitian ini ada juga beberapa saran yang perlu disampaikan kepada beberapa pihak, yaitu: pertama, perlu ada perlindungan hukum yang intensif dari pemerintah, penegak hukum maupun masyarakat terhadap anak yang diasuh di tempat penitipan anak dimana anak yang diasuh di tempat penitipan anak sering mendapatkan perlakuan yang tidak sesuai dengan aturan. Kedua, hendaknya ada peraturan hukum yang mengatur secara tegas mengenai sanksi pidana bagi pelaku tindak pidana kekerasan terhadap anak yang berada di tempat penitipan anak dengan tujuan untuk meningkatkan efek jera terhadap para pelaku tindak pidana kekerasan tersebut, sehingga kedepannya tidak terulang kembali kejadian serupa.

\section{DAFTAR PUSTAKA}

An-Nahlawi, A. (1995). Pendidikan Islam di Rumah Sekolah dan Masyarakat. Jakarta: Gemae Insani Press.

Candra, S. (2018). Pelaksanaan Parenting bagi Orang Tua Sibuk dan Pengaruhnya bagi Perkembangan Anak Usia Dini. ThufuLA: Jurnal Inovasi Pendidikan Guru Raudhatul Athfal, 5(2), 267-287.

Hadjon, P. M. (1987). Perlindungan Hukum bagi Rakyat Indonesia. Surabaya: PT. Bina Ilmu.

Kansil, C. S. T. (1980). Pengantar Ilmu Hukum dan Tata Hukum Indonesia.

Lestari, M. (2017). Hak Anak untuk Mendapatkan Perlindungan Berdasarkan Peraturan PerundangUndangan. Uir Law Review, 1(2), 183-190.

Marlina. (2011). Hukum Penitensier. Bandung: PT Refika Aditama.

Purnamasari, M. L. (2018). Tempat Penitipan Anak Usia Pra Sekolah di Pontianak. Jurnal Online Mahasiswa Arsitektur Universitas Tanjungpura, 6(2), 483-492.

Puspita, H. (2019). Kelekatan Anak dengan Pengasuh Tempat Penitipan Anak. Jurnal PG-PAUD 
Trunojoyo : Jurnal Pendidikan Dan Pembelajaran Anak Usia Dini, 6(1), 49-55.

Waluyo. (2000). Pidana dan Pemidanaan. Jakarta: Sinar Grafika.

Wijaya, M. M. (2015). Perlindungan Hukum terhadap Hak Anak di bawah Umur untuk Mendapatkan Pendidikan. Pakuan Law Review, 1(2), 257-278. 